\title{
APLIKASI PERAMALAN JUMLAH KELAHIRAN DENGAN METODE JARINGAN SYARAF TIRUAN
}

\author{
Safira Amudya Nurdela \\ Departemen Biostatistika dan Kependudukan, Fakultas Kesehatan Masyarakat, \\ Universitas Airlangga, Kampus C Mulyorejo Surabaya, 60115 \\ Email: safiraamudya@gmail.com
}

\begin{abstract}
The forecast is a statistic analysis to predict what it will happen in the future using the data and information from the past. This research aimed to apply Artificial Neural Network method for estimate the fertility rate in Surabaya. The study was descriptive which using secondary data providing from Dinas Kesehatan Kota Surabaya. The study used time series data by recapitulation of fertility rate monthly from 2012-2016. The data analysis used R Program. The result showed the best estimator model for Artificial Neural Network method was 1-3-1 architecture with preprocessing normalized. RMS value of Artificial Neural Network method was 338.1551. The conclusion of this research was the Artificial Neural Network method for estimate the fertility rate in Surabaya could be used for planning birth control program especially Badan Kependudukan dan Keluarga Berencana Nasional.
\end{abstract}

Keywords: artificial neural network, fertility rate, forecast

\begin{abstract}
ABSTRAK
Peramalan merupakan suatu analisis statistik memperkirakan apa yang akan terjadi pada masa yang akan datang dengan menggunakan data dan informasi masa lalu. Penelitian ini bertujuan untuk menerapkan metode Jaringan Syaraf Tiruan dalam memprediksi jumlah kelahiran di Kota Surabaya. Penelitian ini termasuk penelitian deskriptif dengan menggunakan data sekunder. Data yang digunakan yaitu data bulanan jumlah kelahiran di Kota Surabaya tahun 2012-2016. Data diperoleh dengan cara melakukan rekapitulasi jumlah kelahiran di Dinas Kesehatan Kota Surabaya. Analisis data dilakukan dengan bantuan komputer yaitu menggunakan program statistik $R$ square. Hasil yang didapatkan dari penelitian ini antara lain model terbaik untuk metode Jaringan Syaraf Tiruan dengan menggunakan arsitektur 1-3-1 dengan preprocessing normalized. Nilai RMSE yang dihasilkan oleh metode Jaringan Syaraf Tiruan sebesar 338, 1551. Kesimpulan penelitian ini adalah metode Jaringan Syaraf Tiruan dalam meramalkan jumlah kelahiran di Kota Surabaya dapat digunakan sebagai bahan masukan untuk perencanaan program seperti Keluarga Berencana di Badan Kependudukan dan Keluarga Berencana Nasional.
\end{abstract}

Kata kunci: jaringan syaraf tiruan, jumlah kelahiran, peramalan

\section{PENDAHULUAN}

Statistika merupakan suatu ilmu pengetahuan dan mempelajari mengenai bagaimana cara mengumpulkan data, mengolah data, menganalisis data dan menginterpretasikan atau menyajikan data dengan baik sehingga mudah dimengerti (Somantri dan Sambas, 2006). Furqon (2001) juga menyatakan statistika merupakan bagian dari matematika yang secara khusus membicarakan cara-cara pengumpulan, analisis dan penafsiran data.

Menurut Arsyad (2009), peramalan merupakan salah satu aspek dan input dari suatu proses perencanaan. Hasil dari peramalan dapat digunakan untuk mengambil keputusan memilih alternatif yang baik pada proses perencanaan. Peramalan memiliki suatu karakteristik yaitu faktor penyebab yang berlaku di masa 
sebelumnya diasumsikan akan berlaku juga di masa mendatang dan peramalan tak pernah sempurna, permintaan actual selalu berbeda dengan permintaan yang diramalkan (Baroto, 2002).

Menurut Megasari (2011), peramalan dilakukan karena adanya unsur kompleksitas dan ketidakpastian pembuat keputusan yang berhubungan dengan masa depan usaha atau kegiatan yang dijalani. Peramalan yang baik adalah peramalan yang mendekati kenyataan. Hasil suatu peramalan tidak selalu dapat dipastikan kebenarannya dalam hitungan $100 \%$ mutlak, tetapi hal tersebut tidak berarti bahwa peramalan yang dilakukan menjadi percuma. Sebaliknya, peramalan telah banyak digunakan dan membantu dalam hal penjualan.

Peramalan merupakan proses melakukan perkiraan untuk beberapa kebutuhan di masa yang akan datang meliputi kebutuhan dalam ukuran kuantitas, kualitas, waktu dan lokasi yang dibutuhkan dalam rangka memenuhi permintaan barang ataupun jasa (Pakaja et al ., 2013).

Menurut Makridakis (1993) peramalan adalah suatu kegiatan memperkirakan apa yang akan terjadi di masa mendatang. Peramalan dapat dilakukan dengan berbagai cara yaitu dalam bentuk manual atau dengan alat bantu. Pada saat ini proses melakukan peramalan dapat dibantu dengan menggunakan alat bantu yaitu komputer. Sehingga muncul suatu metode peramalan yang disebut jaringan syaraf tiruan. Metode jaringan syaraf tiruan yang sederhana pertama kali dikenalkan oleh McCulloch dan Pitts pada tahun 1943.

Jaringan syaraf tiruan adalah suatu sistem pemroses informasi yang memiliki karakteristik seperti jaringan syaraf biologi (Siang, 2009). Jaringan Syaraf Tiruan merupakan generalisasi model matematika dari jaringan syaraf biologi dengan asumsi bahwa, neuron sebagai sel saraf yang akan mentransformasikan informasi yang diterima. Sinyal dikirimkan di antara neuron melalui penghubung. Penghubung antar neuron memiliki suatu bobot yang akan memperkuat/memperlemah sinyal. Output dari jaringan syaraf tiruan ditentukan dengan fungsi aktivasi.

Jaringan syaraf tiruan merupakan representasi buatan dari otak manusia untuk menyimulasikan proses pembelajaran pada otak manusia. Istilah buatan mempunyai arti bahwa jaringan syaraf tiruan ini diimplementasikan dengan menggunakan program komputer yang mampu menyelesaikan sejumlah proses perhitungan selama proses pembelajaran (Kusumadewi S., 2003).

Menurut Wuryandari (2012) Jaringan syaraf tiruan merupakan suatu sistem pemrosesan informasi yang memiliki karakteristik seperti jaringan syaraf biologis. Jaringan syaraf tiruan merupakan suatu generalisasi model matematis dari pemahaman manusia (human cognition).

Jaringan syaraf tiruan memiliki beberapa arsitektur jaringan yang sering digunakan yaitu jaringan layar tunggal (single layer network), jaringan layar jamak (multi layer network) dan jaringan Reccurent (Siang, 2009).

Backpropagation melakukan pelatihan terhadap jaringan untuk menghasilkan keseimbangan antara kemampuan jaringan untuk memberikan respons yang benar terhadap pola masukan yang serupa namun tidak sama dengan pola yang digunakan selama pelatihan. Arsitektur backpropagation memiliki beberapa bagian yang ada dalam satu atau lebih layar tersembunyi. Arsitektur backpropagation terdiri dari $\mathrm{n}$ buah masukan (ditambah sebuah bias), $p$ unit yang merupakan bagian dari unit layar tersembunyi (ditambah dengan bias), dan $\mathrm{m}$ buah sebagai unit keluaran. Pada algoritma backpropagation, fungsi aktivasi yang dapat digunakan harus memiliki beberapa syarat yaitu kontinu, terdiferensial dengan mudah dan merupakan fungsi yang tidak turun (Siang, 2009).

Pada peramalan dengan menggunakan algoritma backpropagation, data yang 
ada atau record data dipakai sebagai data pelatihan untuk menghasilkan bobot yang optimal. Sehingga perlu ditetapkan besarnya periode dimana data sering mengalami ketidaktetapan. Periode ini ditentukan atas keinginan sendiri. Menentukan jumlah layar atau unit merupakan bagian yang tersulit, teori pasti untuk menentukan jumlah layar atau unit belum ada teori yang dapat mendukung (Siang, 2009).

Hasil residual/error yang dihasilkan dapat digunakan sebagai petunjuk keakuratan sebuah metode peramalan dan merupakan pengukuran statistik. Pengukuran statistik antara lain nilai residual, Mean Absolute Deviation (MAD), Mean Square Error (MSE), Root Mean Square Error (RMSE), Mean Absolute Percentage Error (MAPE) dan Mean Percentage Error (MPE).

Langkah pertama dalam melakukan peramalan adalah mengidentifikasi jenis pola data yang dimiliki. Menurut Hanke dan Winchern (2005) jenis pola data dibagi menjadi empat jenis, yaitu pola horizontal (H) atau Horizontal Data Pattern, Pola Trend (T) atau Trend Data Pattern, pola musiman (S) atau Seasonal Data Pattern dan pola siklis (S) atau Cycled Data Pattern.

Fertilitas atau kelahiran merupakan salah satu faktor penambah jumlah penduduk selain migrasi masuk. Fertilitas sebagai istilah demografi diartikan seorang wanita atau kelompok wanita dapat menghasilkan suatu hasil reproduksi yang nyata. Istilah fertilitas memiliki persamaan dengan kelahiran hidup (live birth), yaitu terlepasnya bayi dari rahim seorang wanita dengan memiliki tanda-tanda kehidupan seperti berteriak, bernapas, jantung berdenyut, dan sebagainya (Mantra, 2003). Di samping itu, ada istilah fekunditas (fecundity) yaitu sebagai petunjuk kepada kemampuan fisiologis dan biologis yang dimiliki seorang perempuan untuk menghasilkan anak lahir hidup.

Menurut Organisasi Kesehatan Dunia (World Health Organization/WHO) lahir hidup atau live birth adalah kelahiran seorang bayi tanpa memperhitungkan lamanya berada di dalam kandungan, di mana bayi telah menunjukkan tanda-tanda kehidupan seperti bernapas, memiliki denyut jantung atau denyut tali pusat atau gerakangerakan otot. Sehingga, peristiwa bayi yang mengalami lahir dalam keadaan tidak hidup/ meninggal (still birth) tidak dimasukkan dalam perhitungan jumlah kelahiran.

Terdapat dua faktor yang dapat memengaruhi peningkatan angka kelahiran, yaitu faktor demografi dan faktor non demografi. Beberapa faktor demografi yang memengaruhi adalah struktur umum, status perkawinan dan umur kawin. Sedangkan untuk faktor non demografi yaitu ekonomi penduduk, tingkat pendidikan, perbaikan status wanita, dan lain-lain (Mantra, 2003).

Angka kelahiran juga dapat dipengaruhi oleh umur memulai hubungan, peningkatan pelayanan kesehatan, kematian janin baik disengaja ataupun tidak disengaja, keluarga berencana (Mantra, 2003).

Fertilitas memiliki dua macam pengukuran, yaitu pengukuran fertilitas tahunan (year performance) dan pengukuran fertilitas kumulatif (reproductive history). Pengertian dari pengukuran fertilitas tahunan (vital rates/current fertility) adalah mengukur jumlah kelahiran pada tahun tertentu dihubungkan dengan jumlah penduduk yang mempunyai risiko untuk melahirkan pada tahun tersebut (Mantra, 2003). Pengukuran fertilitas tahunan terdiri dari angka kelahiran kasar atau Crude Birth Ratio (CBR), angka kelahiran umum atau General Fertility Rate (GFR), angka kelahiran menurut kelompok umur atau Age Specific Fertility Rate (ASFR) dan angka kelahiran total atau Total Fertility Rate (TFR).

Pengukuran fertilitas kumulatif memiliki pengertian ialah mengukur jumlah rata-rata anak yang dilahirkan oleh seorang perempuan hingga mengakhiri batas usia subur. Macam pengukuran fertilitas kumulatif yaitu Children Ever Born (CEB) dan Child Woman Ratio (CWR).

Surabaya merupakan salah satu kota besar yang ada di Provinsi Jawa Timur. Hal 
ini memengaruhi dalam jumlah penduduk yang terdapat di Kota Surabaya.

Menurut Undang-Undang Nomor 23 tahun 2006 tentang administrasi kependudukan, determinan kependudukan yang menyebabkan meningkatnya laju pertumbuhan penduduk adalah fertilitas, mortalitas dan migrasi. Berdasarkan data dari BPS Kota Surabaya, migrasi masuk yang terjadi di Kota Surabaya mengalami peningkatan yang signifikan pada tahun 2012 yaitu sebesar 115.594 jiwa. Hal ini berbanding terbalik dengan migrasi keluar yang terjadi di Kota Surabaya pada tahun 2012 hanya sebesar 30.210. Jumlah kelahiran dan migrasi di Kota Surabaya secara tidak langsung berdampak pada jumlah penduduk dan kepadatan penduduk di Kota Surabaya. Jumlah penduduk di Kota Surabaya menurut data BPS Kota Surabaya mengalami peningkatan pada tahun 2011-2013. Kepadatan penduduk di Kota Surabaya menurut data BPS Provinsi Jawa Timur mengalami peningkatan setiap tahunnya dari tahun 2012 sampai dengan 2016. Sehingga disimpulkan bahwa jumlah penduduk dan kepadatan penduduk di Kota Surabaya sering mengalami peningkatan.

Tujuan penelitian yaitu untuk mengetahui gambaran umum jumlah kelahiran di Kota Surabaya tahun 2012-2016, mengetahui model peramalan untuk peramalan jumlah kelahiran di Kota Surabaya tahun 2017 dengan metode jaringan syaraf tiruan, mengetahui nilai RMSE dari metode jaringan syaraf tiruan untuk peramalan jumlah kelahiran di Kota Surabaya tahun 2017 dengan metode jaringan syaraf tiruan, menarasikan hasil peramalan jumlah kelahiran di Kota Surabaya tahun 2017 dengan menggunakan metode jaringan syaraf tiruan.

\section{METODE}

Metode penelitian yang digunakan yaitu metode unobstrusive. Metode unobstrusive merupakan metode non reaktif sehingga responden tidak sadar sedang dijadikan penelitian. Pada penelitian menggunakan jenis penelitian deskriptif. Populasi pada penelitian yaitu semua data jumlah kelahiran tahun 2012-2016 yang tercatat di Dinas Kesehatan Kota Surabaya. Penentuan sampel penelitian menggunakan total populasi. Variabel penelitian adalah jumlah cakupan bulanan kelahiran dan waktu per bulan dimulai pada tahun 2012 hingga 2016. Teknik pengumpulan data dengan menggunakan data sekunder jumlah kelahiran tahun 2012-2016 di Dinas Kesehatan Kota Surabaya. Analisis data dilakukan dengan menggunakan metode jaringan syaraf tiruan dan bantuan komputer dengan menggunakan program statistik $\mathrm{R}$ square.

\section{HASIL}

Berdasarkan Tabel 1. dapat diketahui bahwa jumlah kelahiran pada tahun 2012-2015 di Kota Surabaya mengalami peningkatan tiap tahunnya, sedangkan untuk tahun 2016 jumlah kelahiran di Kota Surabaya mengalami penurunan. Penurunan jumlah kelahiran pada tahun 2016 di Kota Surabaya tidak mengalami penurunan yang sangat banyak, hanya 1.733 bayi.

Tabel 1. Data Tahunan Jumlah Kelahiran Tahun 2012-2016 di Kota Surabaya

\begin{tabular}{cc}
\hline Tahun & Jumlah Kelahiran \\
\hline 2012 & 41.738 \\
2013 & 45.001 \\
2014 & 46.221 \\
2015 & 48.899 \\
2016 & 47.166 \\
\hline
\end{tabular}

Berdasarkan Gambar 1. Menunjukkan bahwa pola data jumlah kelahiran tahun 2012 - 2016 di Kota Surabaya non stasioner, maka dilakukan differencing 1 sehingga pola data menjadi stasioner dan dapat dilakukan peramalan. 


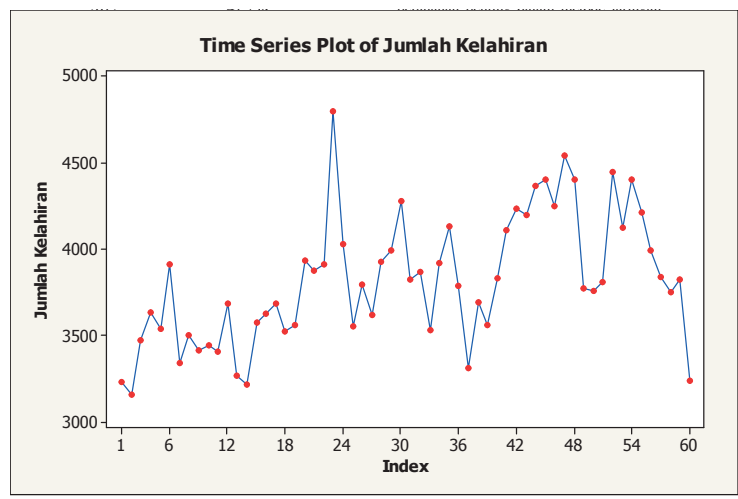

Gambar 1. Pola Data Tahunan Jumlah Kelahiran di Kota Surabaya tahun 2012-2016

Penelitian ini menggunakan metode jaringan syaraf tiruan. Algoritma yang digunakan pada penelitian ini yaitu algoritma backpropagation. Sedangkan untuk fungsi aktivasi pada penelitian ini menggunakan sigmoid biner yang memiliki nilai keluaran antara 0 sampai dengan 1 .

Metode jaringan syaraf tiruan dalam melakukan peramalan perlu menentukan input layer, hidden layer dan output layer. Jumlah input layer sebanyak 1 neuron, output layer sebanyak 1 neuron dan untuk menentukan hidden layer perlu dilakukan proses preprocessing. Proses preprocessing dilakukan tidak hanya untuk menentukan hidden layer saja tetapi menghasilkan nilai RMSE terkecil yang nantinya akan digunakan untuk menyatakan jumlah hidden layer. Proses preprocessing data ini dilakukan sebanyak 9 kali pengulangan. Menurut Crone (2005) mengatakan bahwa tahap preprocessing merupakan tahapan yang mempunyai peranan penting dalam metode jaringan syaraf tiruan. Terdapat tiga model preprocessing yaitu normalized, adjusted dan standardized. Model preprocessing yang digunakan pada peramalan ini adalah model normalized.

Input layer, output layer dan hidden layer akan membentuk arsitektur jaringan. Hidden layer yang akan digunakan pada arsitektur jaringan dapat dilihat pada gambar 2. Sedangkan hasil nilai pengulangan untuk mencari nilai RMSE terkecil dapat dilihat pada tabel 2 .

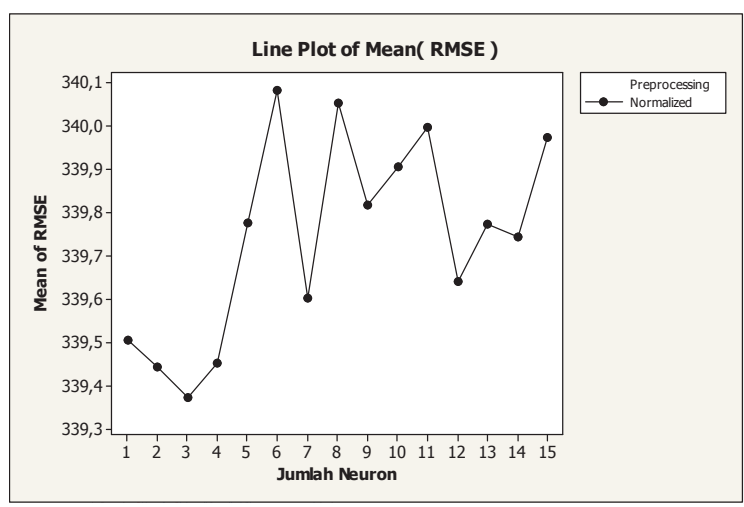

Gambar 2. Preprocessing Normalized

Berdasarkan Gambar 2. layer neuron yang memiliki nilai RMSE terkecil yaitu layer dengan sebanyak 3 neuron. Arsitektur jaringan pada peramalan ini yaitu input layer sebanyak 1 neuron, hidden layer sebanyak 3 neuron dan output layer sebanyak 1 neuron. Sehingga arsitektur jaringan yang digunakan pada peramalan ini yaitu 1-3-1 dengan preprocessing normalized. Tabel hasil pengulangan nilai RMSE untuk menentukan nilai RMSE terkecil terdapat pada tabel 2.

Tabel 2. Hasil Pengulangan Nilai RMSE

\begin{tabular}{cc}
\hline Pengulangan & Nilai RMSE \\
\hline Pengulangan ke -1 & 339,6263 \\
\hline Pengulangan ke -2 & 340,8033 \\
\hline Pengulangan $\mathrm{ke}-3$ & 339,1738 \\
\hline Pengulangan ke -4 & 339,5712 \\
\hline Pengulangan ke -5 & 339,2658 \\
\hline Pengulangan ke -6 & 339,2338 \\
\hline Pengulangan ke-7 & 338,9822 \\
\hline Pengulangan ke -8 & 339,5426 \\
\hline Pengulangan ke -9 & 338,1551 \\
\hline
\end{tabular}

Berdasarkan tabel 2. dapat dilihat bahwa nilai RMSE terkecil berada pada pengulangan yang ke sembilan dengan nilai RMSE sebesar 338, 1551. Sehingga model peramalan yang digunakan untuk meramalkan tahun 2017 dengan arsitektur 
jaringan $1-3-1$ yaitu seperti pada gambar 3.

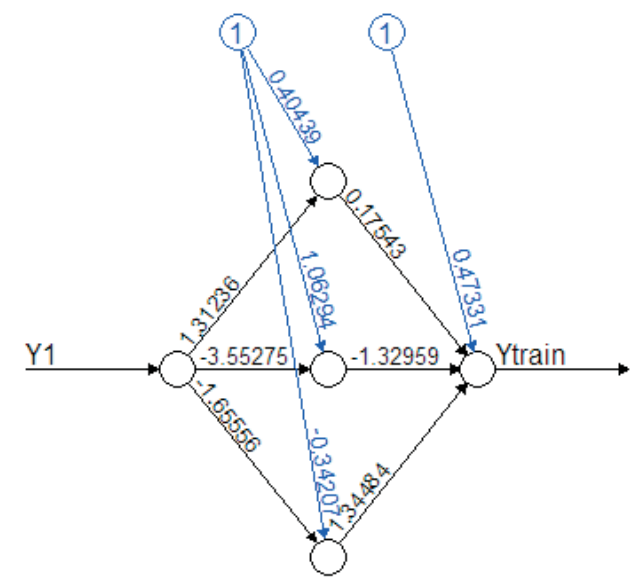

Error: 0.865138 Steps: 435

Gambar 3. Model Peramalan Jumlah Kelahiran Tahun 2017 di Kota Surabaya

Tahap postpreprocessing dilakukan terlebih dahulu sebelum menghasilkan data ramalan. Pada tahap ini akan dilakukan transformasi ke nilai awal terlebih dahulu pada data testing untuk menghasilkan peramalan pada periode selanjutnya.

Tabel 3. Hasil Peramalan Jumlah Kelahiran Tahun 2017 di Kota Surabaya

\begin{tabular}{lc}
\hline \multicolumn{1}{c}{ Bulan } & Jumlah Kelahiran \\
\hline Januari 2017 & 3438 \\
Februari 2017 & 3557 \\
Maret 2017 & 3640 \\
April 2017 & 3730 \\
Mei 2017 & 3751 \\
Juni 2017 & 3787 \\
Juli 2017 & 3815 \\
Agustus 2017 & 3835 \\
September 2017 & 3852 \\
Oktober 2017 & 3864 \\
November 2017 & 3872 \\
Desember 2017 & 3879 \\
\hline
\end{tabular}

Hasil peramalan yang didapatkan menggunakan model persamaan seperti pada gambar 3. yaitu pada bulan Januari 2017 sebesar 3.438 jiwa dan pada bulan
Desember 2017 sebanyak 3.879 jiwa. Jumlah kelahiran pada hasil peramalan dari bulan Januari-Desember Tahun 2017 mengalami peningkatan tiap bulannya.

\section{PEMBAHASAN}

Jumlah kelahiran di kota Surabaya merupakan jumlah kelahiran tertinggi dibandingkan degan kabupaten dan kota lainnya yang ada di Provinsi Jawa Timur. Hal ini sebanding dengan jumlah dan kepadatan penduduk yang terjadi di kota Surabaya. Berdasarkan data BPS diketahui bahwa jumlah migrasi masuk di kota Surabaya lebih tinggi daripada migrasi keluar. Migrasi masuk pada tahun 2014 sebanyak 67.416, sedangkan untuk migrasi keluar pada tahun 2014 hanya sebesar 31.287. Kejadian ini terjadi dikarenakan kota Surabaya merupakan salah satu kota besar yang ada di Provinsi Jawa Timur.

Metode peramalan hingga saat ini sudah banyak bermunculan jenisnya. Terdapat beberapa faktor yang memengaruhi pemilihan metode terbaik yang digunakan untuk meramalkan suatu data, yaitu antara lain banyaknya jumlah data yang akan digunakan, unsur yang ada pada data dan nilai error yang dihasilkan oleh metode peramalan. Menurut Subayo (1986), peramalan merupakan suatu alat bantu yang memiliki peranan penting dalam perencanaan yang efektif dan efisien.

Salah satu metode yang dapat menyelesaikan masalah dalam bidang kesehatan yaitu metode jaringan syaraf tiruan (Kanth et al , 2001; Yuwono 2009). Dalam setiap metode pasti memiliki kelebihan dan kekurangan masing-masing. Metode jaringan syaraf tiruan memilki kelebihan yaitu dapat digunakan untuk menyelesaikan masalah peramalan dalam jangka waktu yang cukup panjang dan memiliki tingkat akurasi yang tinggi (Khashei dan Bijari, 2010). Sedangkan untuk kelemahan metode jaringan syaraf tiruan, penelitian Hendri (2010) mengatakan bahwa kelemahan metode jaringan syaraf tiruan yaitu hanya 
dapat berfungsi sebagai alat bantu. Hal itu disebabkan metode jaringan syaraf tiruan merupakan sistem yang tergolong baru. Kelemahan metode jaringan syaraf tiruan yang lain yaitu memerlukan pelatihan (training) agar dapat bekerja dan dibutuhkan waktu proses yang cukup panjang untuk jaringan yang besar (Sari, 2011). Didukung dengan beberapa penelitian terdahulu yang menunjukkan hasil bahwa metode jaringan syaraf tiruan memiliki tingkat akurasi yang lebih baik dibandingkan dengan metode lain untuk peramalan, maka penelitian dilakukan dengan metode jaringan syaraf tiruan untuk meramalkan jumlah kelahiran tahun 2017 di Kota Surabaya.

Penelitian ini menggunakan arsitektur jaringan layar jamak. Menurut Siang (2009) jaringan layar jamak memiliki proses pelatihan yang lebih kompleks dan lama tetapi dapat menyelesaikan masalah yang lebih kompleks dan baik jika dibandingkan dengan arsitektur jaringan layar tunggal melalui beberapa layer yang terdapat pada jaringan layar jamak. Rusmiati (2010) juga mengatakan pada hasil penelitian yang dilakukan, bahwa metode backpropagation jaringan syaraf tiruan mempunyai kemampuan untuk melakukan peramalan dengan baik dan semakin banyak layer yang digunakan maka semakin kecil kesalahan yang akan dihasilkan.

Hal pertama yang dilakukan pada peramalan adalah mengidentifikasi jenis pola data yang dimiliki. Penelitian ini memiliki jenis pola data trend yang memiliki arti adanya kecenderungan kenaikan atau penurunan yang dialami data pada jangka panjang. Restuwardi (2009) mengatakan berdasarkan penelitian yang dilakukan, metode jaringan syaraf tiruan mampu melakukan peramalan dengan jumlah data yang besar. Jaringan syaraf tiruan memiliki hasil yang lebih baik dalam meminimalkan nilai error yang terjadi akibat adanya perubahan pada data non stasioner dan non homogeny. Analis weight dan bias untuk tiap input yang hendak ditetapkan perlu adanya pengamatan agar mendapatkan hasil yang maksimal. Jaringan melakukan proses kalkulasi yang cepat apabila input mengalami signifikansi yang tinggi sehingga dapat menghemat waktu (Halim and Wibisono, 2000).

Salah satu bidang jaringan syaraf tiruan yang dapat diaplikasikan dengan baik adalah peramalan dan salah satu teknik peramalan yang sering digunakan dalam jaringan syaraf tiruan adalah backpropagation (Setiawan, 2008). Hal itu didukung oleh penelitian yang dilakukan oleh Stepvhanie (2012) yang mengatakan bahwa dari hasil penelitian peramalan penjualan produk susu B dan C dilihat dari nilai MAPE yaitu metode backpropagation jaringan syaraf tiruan memiliki peramalan dengan tingkat akurasi yang paling tinggi bila dibandingkan dengan metode peramalan lainnya. Penelitian Triyono, et al . (2016) juga mengatakan bahwa metode backpropagation jaringan syaraf tiruan mampu menghasilkan nilai akurasi sebesar 99,98\%. Terdapat beberapa faktor yang memengaruhi tingkat akurasi prediksi metode jaringan syaraf tiruan algoritma backpropagation yaitu learning rate, target error, jumlah data yang digunakan dan nilai bobot yang diberikan acak pada tiap neuron. Penentuan parameter besarnya learning rate dan jumlah neuron pada hidden layer sangat berpengaruh dalam menghasilkan nilai untuk menyatakan apakah algoritma backpropagation dapat melakukan prediksi dengan baik (Sudarsono, 2016).

Algoritma backpropagation memiliki beberapa syarat yang harus dipenuhi oleh fungsi aktivasi, yaitu: kontinu, terdiferensial dengan mudah dan merupakan fungsi yang tidak turun. Salah satu fungsi yang banyak digunakan adalah fungsi aktivasi sigmoid biner yang memiliki range $(0,1)$ dan memenuhi ketiga syarat tersebut (Siang, 2009). Lestari (2007) melakukan penelitian dengan metode jaringan syaraf tiruan algoritma backpropagation dengan fungsi aktivasi sigmoid biner. Hasil yang didapatkan yaitu tingkat akurasi peramalan yang baik. 
Penelitian Tanjung (2015) juga menyatakan bahwa peramalan dengan metode jaringan syaraf tiruan algoritma backpropagation dengan fungsi aktivasi sigmoid biner mampu menghasilkan nilai MSE terbaik dan terkecil dari arsitektur jaringan yang lain. Penelitian yang dilakukan Hartanti (2014) menggunakan fungsi aktivasi yang berbeda dengan penelitian ini yaitu fungsi aktivasi sigmoid bipolar, namun hasil peramalan menunjukkan bahwa metode jaringan syaraf tiruan algoritma backpropagation dengan fungsi aktivasi sigmoid biner menghasilkan nilai kesalahan peramalan dan nilai rata-rata error yang lebih kecil dibandingkan dengan metode lain.

Menurut Hermawan (2006), arsitektur sebuah jaringan dapat menentukan keberhasilan target yang ingin dicapai karena tidak semua permasalahan peramalan dapa diselesaikan dengan arsitektur jaringan yang sama. Peramalan menggunakan metode jaringan syaraf tiruan membutuhkan RMSE yang terkecil dalam membuat model peramalan. Menurut (Suliyanto, 2005) semakin kecil nilai persentase nilai residual atau pada penelitian ini yaitu RMSE (root mean square error), maka akan semakin tepat penentuan model peramalan. Sehingga pada penelitian dilakukan proses perbandingan antara tiga jenis preprocessing untuk dipilih dan digunakan meramalkan jumlah kelahiran. Jenis preprocessing yang digunakan pada penelitian yaitu preprocessing normalized karena memiliki perbandingan nilai RMSE terkecil. Setelah itu, dilakukan perbandingan nilai RMSE hidden layer preprocessing normalized dan menunjukkan hidden layer ke-3 preprocessing normalized memiliki nilai RMSE paling kecil sehingga digunakan untuk meramalkan jumlah kelahiran.

Beberapa penelitian melakukan perbandingan nilai kesalahan yang dihasilkan pada saat peramalan. Jaringan syaraf tiruan mampu menghasilkan nilai kesalahan peramalan lebih kecil dibandingkan dengan metode lain. Hal ini didukung oleh penelitian Puspitorini (2010) yang menunjukkan bahwa hasil nilai MSE metode jaringan syaraf tiruan menghasilkan nilai MSE yang lebih kecil dibandingkan dengan metode time series. Suci (2009) juga menyatakan melalui hasil penelitian yang dilakukan bahwa metode jaringan syaraf tiruan mampu menghasilkan nilai error yang lebih kecil bila dibandingkan dengan metode ARIMA. Menurut Hartanti (2014) melakukan penelitian mengenai perbandingan hasil peramalan dengan metode double exponential smoothing holt dan metode jaringan syaraf tiruan. Hasil penelitian menunjukkan bahwa metode jaringan syaraf tiruan lebih tepat digunakan untuk peramalan dikarenakan hasil nilai kesalahan peramalan dan nilai rata-rata error yang dihasilkan metode jaringan syaraf tiruan lebih kecil dibandingkan dengan metode double exponential smoothing holt.

Menurut penelitian Harahap (2013), dilakukan perbandingan metode jaringan syaraf tiruan backpropagation dan metode kohonen pada identifikasi penyakit infeksi pada kulit dengan gejala bercak putih. Penelitian yang dilakukan Harahap tidak sesuai dengan penelitian ini, hasil dari penelitian yaitu metode kohonen lebih cepat dalam mengidentifikasi penyakit infeksi pada kulit dengan gejala bercak putih dibandingkan dengan metode jaringan syaraf tiruan backpropagation. Ketepatan peramalan metode kohonen juga lebih baik dibandingkan jaringan syaraf tiruan backpropagation. Penelitian yang dilakukan Alfina (2012) juga tidak sesuai dengan penelitian ini. Hasil penelitian mengatakan bahwa metode perceptron lebih cepat dalam pelatihan data training bila dibandingkan dengan metode jaringan backpropagation. Penelitian yang dilakukan Rumagit dan Azhari (2013) tidak sesuai dengan penelitian ini. Hasil yang ditunjukkan yaitu metode jaringan syaraf tiruan memiliki nilai MSE paling besar dibandingkan dengan metode ARIMA.

Menurut Arsyad (2009), peramalan ialah merupakan salah satu aspek dan input dari suatu proses perencanaan. Hasil 
dari peramalan dapat digunakan untuk mengambil keputusan dalam memilih alternatif yang baik pada proses perencanaan dan dapat digunakan sebagai program untuk masa mendatang.

Pada bidang kesehatan, peramalan juga diperlukan untuk membuat rencana masa depan, pencapaian sasaran dan tujuan untuk menghadapi masa yang akan datang. Salah satu yang perlu diperhatikan yaitu jumlah kelahiran. Jumlah kelahiran yang terjadi di Kota Surabaya mengalami peningkatan hamper setiap tahunnya.

Menurut Mantra (2003), pengukuran kelahiran lebih rumit bila dibandingkan dengan pengukuran kematian, hal itu terjadi dikarenakan seorang perempuan hanya meninggal satu kali tetapi dapat melahirkan bayi lebih dari satu. Rumitnya pengukuran kelahiran ini dikarenakan kelahiran melibatkan dua orang yaitu suami dan istri. Sedangkan pada kematian hanya melibatkan satu orang saja.

Peran peramalan dalam jumlah kelahiran terdapat pada proses perencanaan yaitu hasil peramalan jumlah kelahiran dapat digunakan untuk melakukan perencanaan dengan program-program pemerintah yang berkaitan dengan kelahiran dan keluarga seperti Keluarga Berencana (KB) sehingga dapat menentukan program prioritas yang harus dilakukan untuk tercapainya target. Hasil peramalan juga dapat digunakan untuk evaluasi tercapainya tujuan di masa datang.

Perencanaan program yang berkaitan dengan kelahiran dan keluarga dapat lebih baik apabila didukung dengan data yang lebih rinci dan lengkap seperti waktu usia ibu pada saat melahirkan, usia pertama ibu melahirkan dan usia ibu menikah. Program yang akan dihasilkan dapat sangat membantu mengurangi atau mengatur kepadatan penduduk dengan baik sehingga setiap tahunnya suatu wilayah mengalami kepadatan penduduk yang tidak melebihi atau kurang dari jumlah yang seharusnya.

Sasaran dari program juga akan lebih jelas dan terarah apabila didukung dengan data yang lebih rinci dan lengkap. Sasaran untuk hasil penelitian ini hanya dapat ditujukan kepada perempuan usia subur yang telah menikah dan berkeluarga dianjurkan untuk menggunakan alat kontrasepsi $\mathrm{KB}$ seperti spiral, IUD dan pil.

\section{SIMPULAN}

Berdasarkan hasil dan pembahasan dalam penelitian ini didapatkan kesimpulan bahwa Jumlah kelahiran di Kota Surabaya menurut Dinas Kesehatan Provinsi Jawa Timur tahun 2012-2015 mengalami peningkatan tiap tahunnya dan pada tahun 2016 jumlah kelahiran di Kota Surabaya mengalami penurunan dari tahun sebelumnya. Jumlah kelahiran di Kota Surabaya pada tahun 2016 sebesar 47.104 bayi.

Model peramalan yang paling tepat dengan metode artificial NN dengan arsitektur jaringan menggunakan preprocessing normalized, jumlah neuron input layer sebanyak 1 neuron, jumlah neuron hidden layer sebanyak 3 neuron, dan jumlah neuron output layer sebanyak 1 neuron.

Peramalan jumlah kelahiran tahun 2017 menggunakan model persamaan dari arsitektur jaringan yang terpilih dengan RMSE sebesar 338, 1551. Hasil peramalan jumlah kelahiran pada titik ke-73 (bulan Januari 2017) sebesar 3.438 bayi dan pada titik ke-84 (bulan Desember 2017) sebesar 3.879 bayi. Hasil peramalan jumlah kelahiran mengalami peningkatan tiap bulannya.

Hasil peramalan tersebut dapat digunakan untuk merencanakan suatu program yang dimiliki pemerintah dan berhubungan dengan kelahiran, seperti Keluarga Berencana (KB) dalam pengendalian pertumbuhan penduduk di masa yang akan datang.

\section{DAFTAR PUSTAKA}

Alfina, O., 2012. Analisis Perbandingan Neural Network Backpropagation dengan Simple Perception dalam Mengenali 
Image Daun. Tesis. Medan: Universitas Sumatera Utara.

Arsyad, L., 2009. Peramalan Bisnis. BPFE: Yogyakarta.

Badan Pusat Statistik Kota Surabaya, 2017. Banyaknya Penduduk Datang yang Dilaporkan per Kecamatan Hasil Registrasi, 2009 - 2014. Surabaya: Badan Pusat Statistik Kota Surabaya. Tersedia di https://surabayakota.bps. go.id/linkTabelStatis/view/id/329 [6 September 2017].

Badan Pusat Statistik Kota Surabaya, 2017. Banyaknya Penduduk menurut Jenis Kelamin Hasil Regristasi Tahun 2008 2014. Surabaya: Badan Pusat Statistik Kota Surabaya. Tersedia di https:// surabayakota.bps.go.id/linkTabelStatis/ view/id/323 [23 Maret 2017].

Badan Pusat Statistik Kota Surabaya, 2017. Banyaknya Penduduk Pindah yang Dilaporkan per Kecamatan Hasil Registrasi, 2009 - 2014. Surabaya: Badan Pusat Statistik Kota Surabaya. Tersedia di https://surabayakota.bps. go.id/linkTabelStatis/view/id/331 [6 September 2017].

Badan Pusat Statistik Provinsi Jawa Timur, 2017. Kepadatan Penduduk Pertengahan Tahun Menurut Kabupaten/Kota, 2012 2016. Jawa Timur: Badan Pusat Statistik Provinsi Jawa Timur. Tersedia di https:// jatim.bps.go.id/linkTabelStatis/view/ $\mathrm{id} / 401$ [6 September 2017].

Baroto, T., 2002. Perencanaan dan Pengendalian Produksi. Jakarta: Ghalia Indonesia.

Crone, S.F., 2005. Stepwise Selection of Artificial Neural Network Models for Time Series Prediction. Journal of Intelligent Systems.

Furqon., 2001. Statistik Terapan untuk Penelitian. Bandung: Alfabeta.

Halim, S., and Wibisono, A. M., 2000. Penerapan Jaringan Syaraf Tiruan Untuk Peramalan. Jurnal Teknik Industri, Vol.2 No.2.
Harahap, R. R., 2013. Perbandingan Jaringan Syaraf Tiruan Backpropagation dan Kohonen Pada Identifikasi Penyakit Infeksi Pada Kulit dengan Gejala Bercak Putih. Skripsi. Medan: Universitas Sumatera Utara.

Hartanti, O. D., 2014. Perbandingan Hasil Peramalan dengan Metode Double Exponential Smoothing Holt dan Metode Jarinan Syaraf Tiruan. Jurnal Biometrika dan Kependudukan, Vol. 3 No. 2.

Hendri, A., 2010. Penerapan Backpropaation Neural Network Untuk Peramalan Penjualan Produk Susu. Skripsi. Institut Pertanian Bogor.

Hermawan, A., 2006. Jaringan Syaraf Tiruan, Teori dan Aplikasi. Yogyakarta: Andi.

Kanth, B.B.M. Khrisna., Kulkarni, U.V., \& Giridhar, B.G.V., 2011. Prediction of Cancer Subtypes using Fuzzy Hypersphere Clustering Neural Network. International Journal of Computer Science and Network Security

Khashei, M. \& Bijari, M., 2010. An Artificial Neural Network $(p, d, q)$ Model For Timeseries Forecasting. Expert System with Application An International Journal.

Kusumadewi, S., 2003. Artificial Intelligence (Teknik dan Aplikasinya). Yogyakarta: Graha Ilmu.

Makridakis, S., 1993. Metode dan Aplikasi Peramalan. Jakarta: Airlangga.

Mantra, I. B., 2003. Demografi Umum. Yogyakarta: Pustaka Pelajar.

Megasari, R. T., 2011. Perbandingan Antara Metode Moving Average, Exponential Smoothing, Winters dalam Peramalan Volume Penjualan PT. Satriamandiri Citramulia Berbasiskan Komputer. Jakarta: Universitas Bina Nusantara.

Pakaja, F., Naba, A., Purwanto, P., 2013. Peramalan Penjulan Mobil Menggunakan Jaringan Syaraf Tiruan dan Certainty Factor. Jurnal EECCIS.

Puspitorini, K., 2010. Peramalan Permintaan Minuman Kesehatan Instan Jahe 
Menggunakan Jaringan Syaraf Tiruan dan Metode Time Series. Jurnal UB.

Restuwardi, Y., 2008. Sistem Intelijen Untuk Prediksi Pertumbuhan Ekonomi dengan Menggunakan Jaringan Syaraf Tiruan dan Adaptif Neuro-Fuzzy. Skripsi. Institut Pertanian Bogor.

Rumagit, S., and Azhari, S. N., 2013. Prediksi Pemakaian Listrik Kelompok Tarif Menggunakan Jaringan Syaraf Tiruan dan ARIMA (Studi Kasus Wilayah Suluttenggo). IJCCS, Vol.7 No.2

Rusmiati, N., 2010. Jaringan Syaraf Tiruan Backpropagation Sebagai Metode Peramalan Pada Perhitungan Tingkat Suku Bunga Pinjaman Di Indonesia. Jurnal Sistem Informasi.

Setiawan, W., 2008. Prediksi Harga Saham Menggunakan Jaringan Syaraf Tiruan Multilayer Feedforward Network Dengan Algoritma Backpropagation. Bali: Konferensi Nasional Sistem dan Informasi.

Siang, J. J., 2009. Jaringan Syaraf Tiruan dan Pemrogramannya Menggunakan Matlab. Yogyakarta: Andi.

Somantri, A. \& Sambas A. M., 2006. Aplikasi Statistika dalam Penelitian. Bandung: Pustaka Ceria.

Stepvhanie, L., 2012. Peramalan Penjualan Produk Susu Bayi dengan Metode Grey System Theory dan Neural Network. Skripsi. Universitas Indonesia.
Subagyo, P., 1986. Forecasting Konsep dan Aplikasi. Yogyakarta: BPFE.

Suci, A. I. B., 2009. Prediksi Penjualan Excavator pada PT. Intraco Penta, Tbk dengan Menggunakan Artificial Neural Network. Skripsi. Universitas Trisakti Jakarta.

Sudarsono, A., 2016. Jaringan Syaraf Tiruan Untuk Memprediksi Laju Pertumbuhan Penduduk Menggunakan Metode Backpropagation (Studi Kasus di kota Bengkulu). Jurnal Media Infotama, Vol.12 No.1.

Tanjung, D. H., 2015. Jaringan Saraf Tiruan dengan Backpropagation untuk Memprediksi Penyakit Asma. Citec Journal, Vol.2 No.1.

Triyono, A., Susanto, A. J., Prawono, 2016. Penerapan Metode Jaringan Syaraf Tiruan Backpropagation Untuk Meramalkan Harga Saham (IHSG). Jurnal Sistem dan Informatika.

Undang-undang Republik Indonesia No.23 Tahun 2006 Tentang Administrasi Kependudukan. Jakarta.

Wuryandari, M. D., 2012. Perbandingan Metode Jaringan Syaraf Tiruan Backpropagation dan Learning Vector Quantization Pada Pengenalan Wajah. Jurnal Komputer dan Informatika (Komputa), Edisi.I Volume.1

Yuwono, B., 2009. Perancangan dan Implementasi Jaringan Syaraf Tiruan Untuk Mendiagnosa Jenis Penyakit Kandungan. Jurnal Teknomatika. 